\title{
THE EFFECT OF INTRAVENOUS ZOLEDRONIC ACID ON GLUCOCORTICOID-INDUCED MULTIPLE VERTEBRAL FRACTURES IN JUVENILE SYSTEMIC LUPUS ERYTHEMATOSUS
}

\author{
Sonia Cristina de Magalhães Souza, Claudia Tereza Lobato Borges, Vanda Jorgetti \\ and Rosa Maria Rodrigues Pereira
}

SOUZA SC de $\mathrm{M}$ et al. The effect of intravenous zoledronic acid on glucocorticoid-induced multiple vertebral fractures in juvenile systemic lupus erythematosus. Rev. Hosp. Clín. Fac. Med. S. Paulo 59(5):302-305, 2004.

Glucocorticoids are widely used in the treatment of lupus patients, and adverse effects, which include osteoporosis and associated fractures, are frequent. Treatment of osteoporosis of young patients should be effective and not harmful to bone growth and remodeling. Bisphosphonates are drugs that decrease the incidence of bone fractures, but their use in juvenile patients is still controversial because of their possible side effects on the growing skeleton. However, recently published studies showed that linear growth continued normally after treatment with these drugs, and there was no excessive suppression of bone remodeling or mineralization defects. Zoledronic acid is a new intravenous bisphosphonate that has been approved by the US FDA for use with hypercalcemia of malignancies and might be an effective treatment for postmenopausal osteoporosis.

The authors report a case of a young girl with systemic lupus who developed multiple vertebral collapses due to glucocorticoid therapy, and zoledronic acid was used producing significant clinical and densitometric improvement.

KEY WORDS: Glucocorticoid-induced osteoporosis. Juvenile osteoporosis. Zoledronic acid. Bisphosphonates.

Glucocorticoids (GC), prescribed because of their immunosuppressive and anti-inflammatory features, are the most common cause of secondary osteoporosis. It is estimated that $10 \%$ of children may require some form of GC at some point in their childhood. ${ }^{1} \mathrm{Im}$ pairment of childhood growth with an approximate cortisone dose of $1.5 \mathrm{mg} /$ $\mathrm{kg}$ /day was first described over 40 years ago; osteopenia in children receiving a prednisolone dose of less than $0.16 \mathrm{mg} / \mathrm{kg} /$ day has also been reported. ${ }^{2,3}$ The incidence of GC-induced osteoporosis is approximately $50 \%$ in patients treated for more than 6 months, and it has been estimated that over $34 \%$ of patients on long-term GC have had fractures. ${ }^{4,5}$ Skeletal wasting appears to be both dose and treatment duration dependent, and the cumulative dose also affects the severity of bone loss. ${ }^{6}$ There is a rapid onset of trabecular bone loss (10\% to $20 \%)$ as early as 3 months after initiation of therapy, followed by a slower rate of $2 \%$ per year thereafter. Osteoporotic vertebral fractures and deformities result in back pain, limitations in physical functioning, psychosocial impair-

From the Division of Rheumatology and Nephrology, Hospital das Clínica, Faculty of Medicine, University of São Paulo - São Paulo/SP, Brazil.

E-mail: rosamariarp@yahoo.com Received for publication on February 27, 2004. ment, and a reduced quality of life. ${ }^{7-8}$ Despite the high prevalence of this iatrogenic morbidity associated with long-term use of glucocorticoid, coprescription of therapy for osteoporosis is low, ranging from $5.6 \%$ to $14 \% .^{9}$

Bisphosphonates are drugs that inhibit osteoclastic bone resorption, increasing bone mineral density and decreasing the incidence of fractures. Oral administration of these drugs causes esophageal irritation and injury, and their low bioavailability and low potency necessitate frequent administration on an empty stomach (which may reduce compliance). Intermittent intravenous bisphosphonates may be a way to avoid the problem associated 
with oral administration. Zoledronic acid is an intravenous bisphosphonate. On the basis of in vitro studies and animal models of osteoclast-mediated bone resorption, this drug is the most potent biphosphonate among a large number of other compounds tested. This drug maintains bone mass in estrogen-deficient animals without an adverse effect on mineralization. ${ }^{10}$ In postmenopausal women, zoledronic acid produces an effect on bone turnover and bone density as great as those achieved with daily oral administration of other bisphosphonates, with proven efficacy against fractures with only an annual infusion. ${ }^{11}$ Moreover, it has demonstrated efficacy in the reduction of skeletal events in patients with multiple myeloma, metastatic breast cancer, prostate cancer, or other solid tumors and hypercalcemia of malignancy.

The use of bisphosphonates in juvenile patients is still controversial because of their possible side effects on the growing skeleton. The authors searched the Medline and Lilacs databases for text words, zoledronic acid, osteoporosis, and children, in the title, keywords, and abstracts and could not find another published case in which the zoledronic acid was used in a child or an adolescent for any reason.

The authors report a case of a young girl with systemic lupus who developed multiple vertebral collapses due to glucocorticoid therapy, and zoledronic acid was used, producing significant clinical and densitometric improvement.

\section{CASE REPORT}

A 13-year-old Caucasian girl was admitted to our hospital from another medical center 8 months after diagnosis of systemic lupus. At presentation, she had cutaneous vasculitis, polyar- thritis, pericarditis, and high levels of anti-DNA antibodies. At that time, she could not walk or sit and could hardly move in bed. She had a history of 2 episodes of dorsal pain after rough movements and could not move because of the pain. She had been taking prednisone and azathioprine since the diagnosis. Calcium, vitamin D, and calcitonin (200 UI/day nasal) were initiated after the first episode of dorsal pain, which occurred in the fourth month after the diagnosis (by this time she had already received a cumulative dose of prednisone of $8.25 \mathrm{~g}$ ). On this occasion, she had vertebral fractures in $\mathrm{T} 2$ and $\mathrm{T} 5$ revealed by her first $\mathrm{x}$-ray. At her admission in our hospital, biochemical markers, dual-energy x-ray absorptiometry (DXA), new spinal $\mathrm{x}$ rays, and a bone biopsy were performed. Serum levels of calcium, phosphorus, alkaline phosphatase, and PTH were normal. The DXA showed a spine (L1 to L4) bone mineral density $(\mathrm{BMD})=0.444 \mathrm{~g} / \mathrm{cm}^{2}$ with a $z$ score $=$ -4.27 , a femoral neck BMD $=0.610$ $\mathrm{g} / \mathrm{cm}^{2}$, and a whole body BMD = $0.735 \mathrm{~g} / \mathrm{cm}^{2}$. Spine x-ray revealed generalized thoracic and lumbar vertebral collapse (Figure 1). Bone biopsy per- formed at the iliac crest, after informed consent by parent, showed reduction in the cancellous volume, trabecular thinning, and disconnections of trabecula (Figure 2). Tetracycline labeling was observed only in cortical bone.

The patient was medicated with endovenous zoledronic acid (4 $\mathrm{mg}$, once), since she could not receive oral

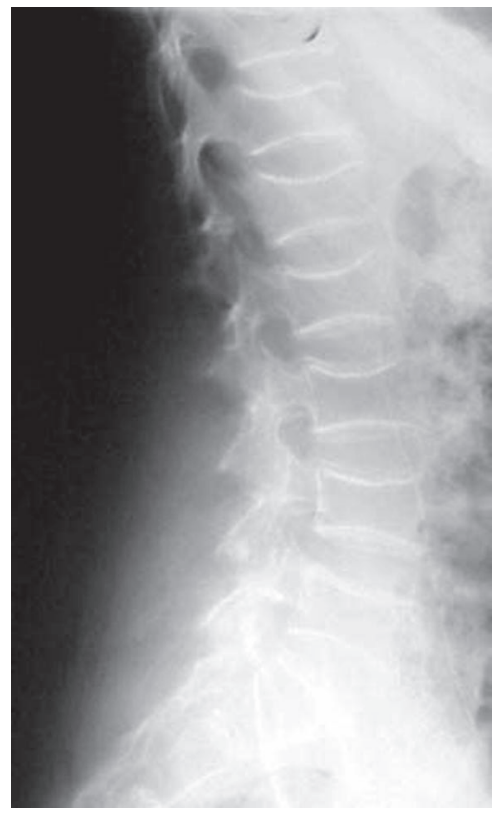

Figure 1 - Spine x-ray revealed generalized thoracic and lumbar vertebral collapse.

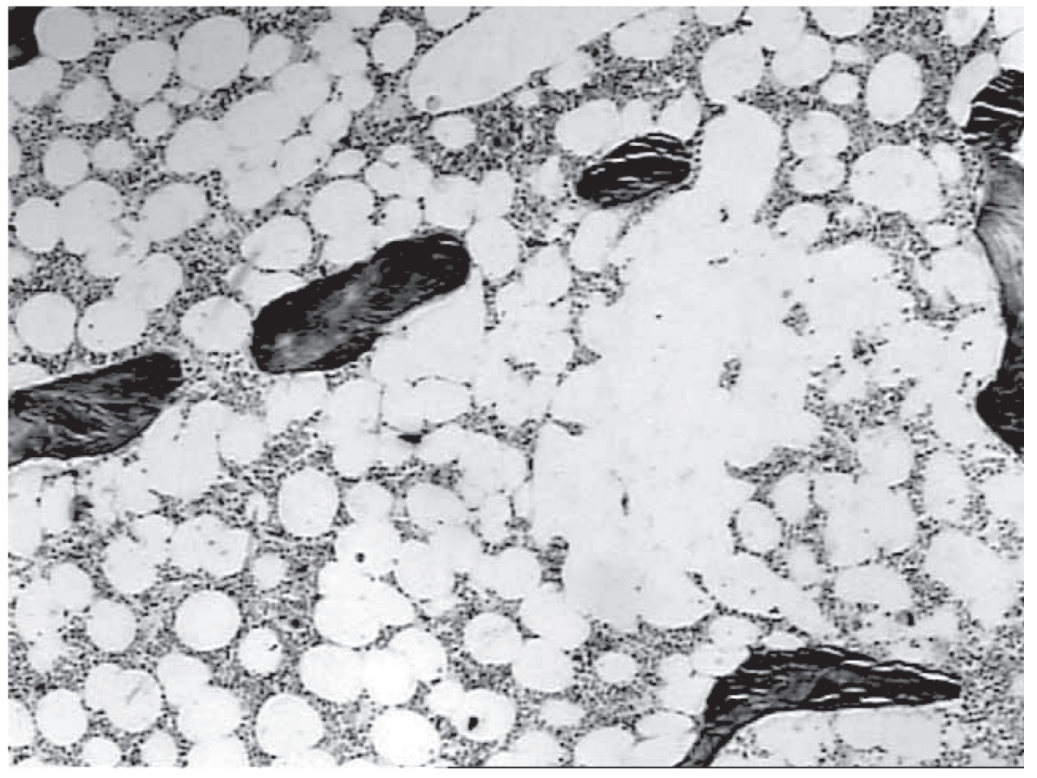

Figure 2 - Bone biopsy showed reduction on the cancellous volume, trabecular thinning, and disconnections of trabecula. 
bisphosphonate because of the high possibility of developing esophagitis. A month later, she gradually started walking again. New bone density determinations 6 months after zoledronic acid administration revealed for the lumbar spine (L1-L4) a $\mathrm{BMD}=0.579 \mathrm{~g} / \mathrm{cm}^{2}, z$ score $=-3.18$ (an increase of $52 \%$ ); for the femoral neck BMD $=0.610 \mathrm{~g} / \mathrm{cm}^{2}$ (an increase of $12.8 \%$ ); and for whole body BMD $=0.784 \mathrm{~g} / \mathrm{cm}^{2},($ an increase of $11.2 \%)$.

Currently, the patient has an inactive disease, and she is using a low dose of prednisone (2.5 mg/day). We are planning to further reduce the glucocorticoid and maintain this patient with azathioprine and chloroquine. Regarding the osteoporosis treatment, she is only using calcium, vitamin $\mathrm{D}$, and the BMD will be repeated each year. If the BMD remains very low (T score <-2.5) and if she will need $5 \mathrm{mg} /$ day or more of glucocorticoid for more than 3 months, she will receive zoledronic acid $4 \mathrm{mg} /$ year or another bisphosphonate (alendronate: 70 $\mathrm{mg} /$ week or $10 \mathrm{mg} /$ day, oral) depending on the availability of these drugs in our hospital. Because bisphosphonates are not indicated to be used during pregnancy and the long-term side effects of bisphosphonate use on the fetus are unknown, we will advise her to avoid pregnancy, and we will also try to prescribe this drug for the shortest time possible.

\section{DISCUSSION}

Current studies and clinical observations suggest that children who require long-term systemic GC therapy have a higher incidence of fractures during their use. ${ }^{12,13}$ For adults, the American College of Rheumatology recommends life style adaptations, supplementation with calcium and vitamin $\mathrm{D}$, and bisphosphonates in patients receiving, or initiating therapy with prednisone equivalent of $\geq 5 \mathrm{mg} /$ day. ${ }^{14} \mathrm{In}$ the absence of any clear guidelines for children, it is important to monitor susceptible patients carefully with review of bone symptomatology, GC dosage, nutrition, anthropometry, and pubertal and bone mineralization status. Children at high risk for GC-induced osteoporosis and those displaying growth failure should have serial bone mineral density assessments. Prevention of GCinduced growth retardation could be addressed in a number of cases by a prudent use of GC therapy, improved nutrition, and promotion of weight-bearing activities. Calcium and vitamin D supplementation should always be recommended.

The bisphosphonates decrease bone resorption and turnover and reduce the incidence of bone fractures, being recommended for the treatment and prevention of corticosteroid-in- duced osteoporosis in adults. ${ }^{14}$ The use of bisphosphonates in children and adolescents is still controversial because of their possible harmful effects on the growing skeleton. The role of antiresorptive drugs (bisphosphonates) has been mostly studied in the field of osteogenesis imperfecta where their use is associated with a reduction in the frequency of fractures and improvement of bone mass and mobility. ${ }^{15}$ Published studies in children with osteogenesis imperfecta have shown that linear growth continued normally on treatment, and there was no excessive suppression of bone remodeling or mineralization defects. ${ }^{16}$

Our patient had a debilitating condition caused by the vertebral fractures, in which she could not even sit up in bed to take medications, and the risk of esophageal irritation and injury with the use of oral bisphosphonates was not small. Additionally, the prolonged period of immobility was very detrimental, since it could promote further fractures. For these reasons, an intravenous, highly potent bisphosphonate was prescribed, and significant clinical and densitometric improvement was observed. Further prospective clinical trials should be carried out to accurately define the efficacy and safety of this drug in osteoporotic juvenile patients.

\section{RESUMO}

SOUZA SC de M e col. Efeito do ácido zoledrônico nas múltiplas fraturas vertebrais induzidas por glicocorticóide no lúpus eritematoso juvenil. Rev. Hosp. Clín. Fac. Med. S. Paulo 59(5):302-305, 2004.

Glicocorticóides são fármacos comumente usados no tratamento de pacientes lúpicos, porém apresentam efeitos adversos importantes, principalmente a osteoporose e fraturas. $\mathrm{O}$ tratamento da osteoporose em pacientes jovens deve ser eficaz e não prejudicial ao crescimento e remodelamento ósseo. Os bisfosfonatos são drogas que reduzem a incidência de fraturas, mas seu uso em crianças e adolescentes ainda é controverso, devido a seus possíveis efeitos adversos no esqueleto em crescimento. Estudos recentemente publicados demonstraram que o crescimento linear se manteve normal com o uso de bisfosfonatos, não havendo supressão excessiva do remodelamento ósseo ou defeitos de mineralização. O ácido zoledrônico é um novo bisfosfonato endovenoso aprovado pelo FDA para o uso na 
hipercalcemia das neoplasias e parece ser um tratamento eficaz para a osteoporose pós-menopáusica.

Os autores descrevem um caso de uma adolescente lúpica que desenvol- veu múltiplas fraturas vertebrais induzidas pelo glicocorticóide e obteve importante melhora clínica e densitométrica após o tratamento com o ácido zoledrônico.
UNITERMOS: Osteoporose induzida por glicocorticóide. Osteoporose juvenil. Ácido zoledrônico. Bisfosfonatos.

\section{REFERENCES}

1. Warner JO. Review of prescribed treatment for children with asthma in 1990. BMJ 1995;311:663-6.

2. Blodget FM, Burgin L, Iezzoni D, Gribetz D, Talbot NB. Effects of prolonged cortisone therapy on the statural growth, skeletal maturation and metabolic status of children. N Engl J Med 1956;254:636-41.

3. Avioli LV. Glucocorticoid effects on statural growth. Br J Rheumatol 1993;32:27-30.

4. Sambrook PN. Corticosteroid osteoporosis: practical implications of recent trials. J Bone Miner Res 2000;15:1645-9.

5. Michel BA, Block DA, Fries JF. Predictors of early fractures in early rheumatoid arthritis. J Rheumatol 1991;18:804-8.

6. Van Staa TP, Leufkens HG, Abenhaim L, Zhang B, Cooper C. Use of oral corticosteroids and risk of fractures. J Bone Miner Res 2000;15:993-1000.

7. Ettinger B, Black DM, Nevitt MC, Rundle AC, Cauley JA, Cummings SR, et al. Contribution of vertebral deformities to chronic back pain and disability. J Bone Miner Res 1992;7:44956.

8. Lyles KW, Gold DT, Shipp KM, Pieper CF, Martinez S, Mulhausen PL. Association of osteoporotic vertebral compression fractures with impaired functional status. Am J Med 1993;94:595-601.

9. Walsh LJ, Wong CA, Pringle M, Tatterfield AE. Use of oral corticosteroids in the community and the prevention of secondary osteoporosis. A cross sectional study. BMJ 1996;313:344-6.
10. Hornby SB, Evans GP, Hornby SL, Pataki A, Glatt M, Green JR. Long-term zoledronic acid treatment increases bone structure and mechanical strength of long bones of ovariectomized adult rats. Calcif Tissue Int 2003;72(4):519-27.

11. Reid IR, Brown JP, Burckhardt P, Horowitz Z, Richardson P, Trechsel $\mathrm{U}$, et al. Intravenous zoledronic acid in postmenopausal women with low mineral density. N Eng J Med 2002;346:653-61.

12. Varonos S, Ansell BM, Reeve J. Vertebral collapse in juvenile chronic arthritis: its relationship with glucocorticoid therapy. Calcif Tissue Int 1987;41:75-8.

13. Murray KJ, Boyle RJ, Woo P. Pathological fractures and osteoporosis in a cohort of 103 systemic onset juvenile idiopathic arthritis patients. Arthritis Rheum 2000;43:S119.

14. American College of Rheumatology Ad Hoc Committee on Glucocorticoid-Induced Osteoporosis. Recommendations for the prevention and treatment of glucocorticoid inducedosteoporosis. Arthitis Rhem 2001;44:1496-503.

15. Glorieux FH, Bishop NJ, Plotkin H, Chabot G, Lanoue G, Travers R. Cyclic administration of pamidronate in children with severe osteogenesis imperfecta. N Eng J Med 1998;339:947-52.

16. Brumsen C, Hamdy NAT, Papapoulos SE. Long-term effects of bisphosphonates on the growing skeleton: studies of young patients with severe osteoporosis. Medicine (Baltimore) 1997;76:266-83. 